\title{
Effect of Drip Irrigation and Fertigation on Growth, Development and Yield of Vegetables and Fruits
}

\author{
A. Raja Gopala Reddy*, D.T. Santosh and K.N. Tiwari \\ PFDC, IIT Kharagpur, West Bengal, India \\ *Corresponding author
}

\begin{tabular}{|c|c|}
\hline & A B S T R A C T \\
\hline $\begin{array}{l}\text { K e y w o r d s } \\
\text { Drip, Fertigation, } \\
\text { Irrigation, } \\
\text { Fruits, } \\
\text { Vegetables, Yield. }\end{array}$ & \multirow{3}{*}{$\begin{array}{l}\text { Drip irrigation has the greatest potential for the efficient use of water and fertilizers. The } \\
\text { limited area of wetting under trickle irrigation reduces the active root zone and also the } \\
\text { foraging area of plants to draw water and nutrients from the soil. For minimizing the cost } \\
\text { of irrigation and fertilizers, adoption of drip irrigation with fertigation is essential which } \\
\text { will maximize the nutrient uptake, while using minimum amount of water and fertilizer. } \\
\text { Fertigation gives advantages such as higher use efficiency of water and fertilizer, } \\
\text { minimum losses of N due to leaching, supplying nutrients directly to root zone in available } \\
\text { forms, control of nutrient concentration in soil solution and saving in application cost. } \\
\text { Thus, fertigation becomes privilege for increasing the yield of most of the crops under drip } \\
\text { irrigation. In this paper, the literatures pertaining to the different aspects of fertigation and } \\
\text { irrigation are reviewed. }\end{array}$} \\
\hline Article Info & \\
\hline $\begin{array}{l}\text { Accepted: } \\
\text { 24 January } 2017 \\
\text { Available Online: } \\
\text { 10 February } 2017\end{array}$ & \\
\hline
\end{tabular}

\section{Introduction}

Drip irrigation, also known as micro irrigation or trickle irrigation, applies water slowly, directly to the soil around the crop. Drip irrigation generally uses less than half the water of overhead and furrow irrigation. Efficiency with drip irrigation exceeds $90 \%$ whereas a sprinkler system is between 50 to $70 \%$ efficient. The high efficiency of drip irrigation is due to I) the water soaking into the soil before it can evaporate or run off and ii) application of water only where it is needed (near the crop) rather than over the entire field. iii) Reduces weed growth. iv) Another advantage of drip irrigation is that it reduces water contact with above ground crop growth (leaves, stems, and fruit) thus making conditions less favorable for many diseases.
Drip irrigation is most suitable for row crops (vegetables, soft fruit), tree and vine crops where one or more emitters can be provided for each plant. Generally only high value crops are considered because of the high capital costs of installing a drip system. Drip irrigation is suitable for all soils. On clay soils water must be applied slowly to avoid surface water ponding and runoff. On sandy soils higher emitter discharge rates will be needed to ensure adequate lateral wetting of the soil. Drip irrigation and fertigation favors crop growth and yield of many fruit and vegetable crops.

Fertigation is the application of fertilizer with irrigation water. Fertilizer can be applied 
using any irrigation system. In fruit and vegetable production, drip irrigation is the most common system used for fertigation and requires the most knowledge for effective use.

\section{Advantages of drip irrigation}

1. Maximum use of available water.

2. No water being available to weeds.

3. Maximum crop yield.

4. High efficiency in the use of fertilizers.

5. Less weed growth and restricts population of potential hosts.

6. Low labour and relatively low operation cost.

7. No soil erosion.

8. Improved infiltration in soil of low intake.

9. Ready adjustment to sophisticated automatic control.

10. No runoff of fertilizers into ground water.

11. Less evaporation losses of water as compared to surface irrigation.

12. Improves seed germination.

13. Decreased to tillage operations.

\section{Disadvantages of drip irrigation}

1. Sensitivity to clogging

2. Moisture distribution problem

3. Salinity hazards

4. High cost compared to furrow. 5. High skill is required for design, install and operation.

\section{Under vegetable crops}

Vijayakumar et al., (2010) studied that in chili, the maximum yield was observed in drip irrigation along with fertigation of $75 \%$ of recommended $\mathrm{N}$ and $\mathrm{K}$ with maximum shoot length and more number of branches. Swarajyalakshmi et al., (2005) reported that the highest green chilli yield (21.56 $\left.\mathrm{t} \mathrm{ha}^{-1}\right)$ was recorded through drip method scheduled at 0.8 ET under black polythene mulch. This increase was accounted to 34 per cent over conventional method of irrigation practiced. Waldir et al., (2007) proved that in tomato maximum fruit yield was reached when irrigations were performed at SWT thresholds of 35,12 , and $15 \mathrm{kPa}$ during vegetative, fruit development, and maturation growth stages. Ngouajio et al., (2007) showed that drip irrigation along with fertigation at flowering and fruit development stage increased tomato yield by $8-15 \%$, fruit number by $12-14 \%$ over control treatment. Monte et al., (2013) proved that increase in irrigation depth above $80 \%$ of Etc, increased crop growth rate (CGR), leaf area index (LAI) and total production of tomato fruits. Harmanto et al., (2005) concluded that the drip irrigation at $75 \%$ of ETc provided the maximum crop yields and irrigation water productivity in tomato variety Troy 489 under tropical greenhouse conditions. Ughade and Mahadkar (2014) reported that the brinjal crop under Field water use efficiency (FWUE) was maximum under treatment $80 \%$ ET with100 $\%$ RDF drip fertigation while comparing with 100 and $60 \%$ ET with RDF drip fertigation. Patel and Rajput (2007) reported that the potato yield was Maximum when irrigation was applying at the $100 \%$ of the crop evapotranspiration $(23.6 \mathrm{~cm}$ of irrigation water) and by placing the drip tape at $10.0 \mathrm{~cm}$ depth followed by $15.0 \mathrm{~cm}$ and $20.0 \mathrm{~cm}$ depth. Yuan et al., (2003) reported that the amount of increasing irrigation water had significant effects on decreasing the canopy temperature and increasing the Total fresh tuber yields and marketable tuber yields $(>85$ g).Chun-Zhi Zeng et al., (2009) showed that fruit quality and quantity of muskmelon yield under $90 \%$ of field water capacity is the suitable soil irrigation which can save irrigation water and improve the quality of fruit. Singandupe et al., (2007) reported in brinjal that irrigation at 80 per cent ET (6.3 tonnes) has given at par yield with 100 per cent ET (6.45 tonnes). Kaushal et al., (2012) reported that the drip irrigation adoption 
increased water use efficiency (60-200\%), saved water $(20-60 \%)$, reduced fertilization requirement (20-33\%) through fertigation, produced better quality crop and increased yield (7-25\%) in capsicum as compared with conventional irrigation. Mahajan and Singh revealed that drip irrigation at 0.5 pan evaporation with fertigation at 100 per cent recommended nitrogen resulted in increased tomato fruit yield by 59.5 per cent compared to conventional method. Imtiyaz et al., recorded that the higher marketable cabbage yield of $74.26 \mathrm{t}$ ha-1 was observed in drip irrigation at $11 \mathrm{~mm}$ CPE compared to $22 \mathrm{~mm}$ CPE (72.39 t ha-1) and $33 \mathrm{~mm} \mathrm{CPE}(45.23 \mathrm{t}$ ha-1). Sharmasarkar et al., reported that sugar beet yields and sugar contents under drip irrigation were higher (3-28 per cent) than those with flood irrigation. Hebbar et al., revealed that the total dry matter production and leaf area index of tomato were significantly higher in drip irrigation $(165.8 \mathrm{~g}$ and 3.12 respectively) over furrow irrigation with the higher fruit yield of 19.9 per cent in drip irrigation (71.9 Mg ha-1) over furrow irrigation (59.50 Mg ha-1). Antony and Singandhupe concluded that the drip irrigation at 100 per cent CPE recorded the maximum capsicum yield of $99.97 \mathrm{~g}$ plant-1 compared to drip irrigation at 80 and 60 per cent CPE. Muralidhar et al., reported that the drip fertigation at 80 per cent of recommended $\mathrm{N}$ and $\mathrm{K}$ level with water soluble fertilizers registered higher tomato yield (22.3 t ha-1) compared to 100 per cent and 60 per cent of recommended levels in drip irrigation.

Battilani and Solimando (2010) studied that water melon crop under Static and Dynamic fertigation increased commercial yield by $33.7 \%$ and $57.7 \%$ while comparing with the no irrigation and fertilised treatment. Liu Hucheng et al., (2014) showed that the ginger yield has increased by $17.94 \%$ in drip fertigation comparing with $15.78 \%$ in conventional irrigation and fertigation Tanaskovik et al., (2011) reported that in tomato drip fertigation treatments $100 \%$ and $75 \%$ shows greater yield and increases $28 \%$ of WUE comparing with conventional fertilizer application and $87 \%$ in case of furrow method. Jan Rumpel et al., (2007) reported that onion yield were greater with $150 \mathrm{~kg} / \mathrm{ha} \mathrm{N}$ through fertigation (79\%) followed by $50 \mathrm{~kg} / \mathrm{ha} \mathrm{N}$ was applied through drip fertigation $(41 \%)$ over control (Nitrogen without fertigation).Imamsaheb et al., (2011) revealed that the application of 100 per cent fertilizers through water soluble fertilizer through drip at 80 per cent evaporation resulted in significantly higher growth attributes viz., plant height $(96.70 \mathrm{~cm})$, number of branches (18.25), stem diameter $(2.06 \mathrm{~cm})$ and leaf area index (3.49).Neelam and Rajput (2005) reported that in onion that the highest yield was recorded in daily fertigation (29.2t/ha) followed by alternate day fertigation $(28 \mathrm{t} / \mathrm{ha}$ ) while the lowest yield was recorded in monthly fertigation (22.4t/ha). Ananta (2006) reported that the highest fruit yield of tomato was noticed when nitrogen was supplied in 80 or 10 split doses with 100 per cent ET through drip irrigation. Singandhupe et al., (2007) reported that the pointed gourds (Trichosanthes dioica) grown by using fertilizer through drip irrigation system with 100 percent recommended dose at monthly interval gave higher yield of 4.27 tonnes per hectare. Kaniszewski et al., (1999) reported that fertigated celeriac plants had greater leaf area, dry matter production, and nitrate- $\mathrm{N}$ and total $\mathrm{N}$ contents than those given through broadcast $\mathrm{N}$ with or without drip irrigation. Kapoor et al., (2014) showed that increase in NPK fertigation level from 33.3 to $100 \%$ RDF significantly increased number of leaves, relative leaf water content, and marketable yield of cauliflower in comparison to flood and conventional fertilizer application. Veeranna et al., (2001) reported that $80 \%$ 
water soluble fertilizer (WSF) was effective in producing about 31 and $24.7 \%$ higher chilly fruit yield over soil application of normal fertilizers at $100 \%$ recommended level in furrow and drip irrigation methods, respectively, with $20 \%$ of saving in fertilizers. Roy et al., (2011) showed in capsicum that the length and width of fruit and number of fruits per plant increased significantly with increasing nitrogen doses up to $100 \mathrm{~kg} \mathrm{~N} / \mathrm{ha}$. Dingre et al., (2012) showed that drip fertigation resulted into 12 to $74 \%$ increase in the productivity of onion seed as compared to conventional method. The total irrigation water applied through surface and drip system was $840 \mathrm{~mm}$ and $520.45 \mathrm{~mm}$ indicating 39\% water saving whereas, field water use efficiency of drip fertigation was more by 2.5 times as that of control. Dawelbeit and Ritcher (2004) observed that the drip fertigation system in onion produced higher yields compared to drip irrigation with fertilizer broadcasting.

\section{Under fruit crops}

Baskar recorded the highest yield of banana with maximum water use efficiency of 2.18 $\mathrm{kg}$ ha-1 cm-1 in drip fertigation at 75 per cent of recommended NPK level compared to drip fertigation at 100 and 50 per cent of recommended NPK levels. Rao and Subramanyam (2007) reported that 50\% recommended dose (250 g /plant) of nitrogen through fertigation at fortnight intervals enhanced yield in pomegranate/tree under low rain fall zone. It saved $50 \%$ nitrogen fertilizers and labour cost. Firake\&Kumbhar (2002) on pomegranate revealed that the maximum yield obtained (11.88 tha-1) due to $100 \%$ RDF through drip was superior over $100 \%$ RDF application through conventional fertilizers and it was at par with $70 \%$ RDF through drip with water soluble fertilizers and it saves about 30\% RDF under drip irrigation over conventional method. Agarwal et al.,
(2014) reported that the fertigation studies on pomegranate shows the economic yield of $52.5 \mathrm{q} \mathrm{ha}^{-1}$ and highest benefit cost ratio of 3.21 were recorded in pomegranate under 80 per cent of fertigation with water soluble fertilizers. Shanmugasundaram and Balakrishnamurthy (2013) investigated in pomegranate $\mathrm{cv}$. mridula showed that $50 \%$ $\mathrm{RDF}$ in the form of water soluble fertilizers increased flowering and the highest yield from 3rd year on wards. Ramniwas et al., (2012) reported that 'Shwetha' cultivar of guava shows $75 \%$ RDF and $75 \%$ irrigation of IW/CPE through drip resulted in notably greater number of flowers per shoot (32.02), fruit set $(45.88 \%)$, fruit retention $(47.83 \%)$ and fruit yield of $29.33 \mathrm{t} / \mathrm{ha}$. LU Yong et al., (2013) showed that while comparing with traditional fertilization treatment, fertigation treatment increased the yield of fuji apple by $13.0 \%$ and the fruit hardness increased by $10.6 \%$ and the sugar content improved by $7.3 \%$, meanwhile, fruit weight, shape index and the content of chlorophyll in leaves also showed an increasing trend. Wassel et al., (2007) showed that the influence of nitrogen fertigation and drip irrigation on fruit setting; number of fruits per tree and fruit weight in litchi Nitrogen was used at 0.4, 0.6, 0.8 and $1.0 \mathrm{k} \mathrm{g} /$ tree annually. Results revealed that initial and final fruit setting were increased by raising the amount of water and nitrogen. Ashokraja (2011) found that fertigation in Muscat Grapes at $125 \%$ RDF was superior to $100 \%$ RDF and it increases Muscat grape fruit yield (27.5 tons/ha) was possible with WSF at $125 \%$ dose. Mursaleen (2014) Studies on guava revealed that $100 \%$ water soluble fertilizers gave maximum plant height, canopy fruit weight $(182.17 \mathrm{~g})$, yield/plant $(6.59 \mathrm{~kg})$ compare other doses of fertilizers. Jeyakumar et al., (2010) proved that the papaya has showed positive response to $100 \%$ $\mathrm{RDF}$ of $\mathrm{N}$ and $\mathrm{K}$ through drip irrigation resulted in flowering at the shortest height $(96.32 \mathrm{~cm})$, stem girth, number of leaves, 
number of fruits, fruit weight, TSS and low fruit cavity index were also found significantly in $100 \% \mathrm{RDF}$ of $\mathrm{N}$ and $\mathrm{K}$ through drip while comparing with the soil application of fertilizers. Castellanos et al., (2013) reported that the highest yields were obtained with a dose of about $160 \mathrm{~kg} \mathrm{ha}^{-1}$ of nitrogen through fertigation and over doses causes negative effects on yield, WUE and loss of nitrate leaching. Liang-zhi et al., recommended that drip fertigation with 4 times/ year effects on increasing fruit yield with $29.4 \%-36.5 \%$ more accumulative yield than the 10 times/year and 16 times/year.

Shirgure (2013) observed that while comparing with plant height and girth the only canopy volume was found significant among the various scheduling irrigation treatments and the highest fruit was observed under irrigation at $80 \% \mathrm{ER}$ in stages I-V and $30 \%$ ER in stage VI during the study period. Tank and Patel (2013) proved that the papaya under drip irrigation revealed that 0.8 PEF with $100 \%$ recommended dose of N\&K shows the maximum yield and greater individual fruit weight and they are at par with treatment drip irrigation @ 0.8 PEF with $80 \%$ recommended dose of N\&K. Shirgure et al., (2003) studied the effect of irrigation scheduling and fertigation through drip irrigation on 6-8-year-old acid lime which shows that TSS, fruit yield average fruit weight, juice percent and acidity $(42.5 \%$ and $7.0 \%$ ) was more in irrigation scheduled at 30 $\%$ depletion of available water content with 500:140:70 fertigation. Khan et al., (2013) studied in guava that the controlling Soil moisture potential between $-40 \mathrm{kPa}$ to $-45 \mathrm{kPa}$ at $0.2 \mathrm{~m}$ depth immediately under the drip emitter and fertilizer dose of $80 \%$ recommended dose of fertilizer can be used as an indicator for drip irrigation scheduling in semi-arid region of India. Mandal et al., (2007) concluded that the guava plants planted at $5 \times 5 \mathrm{~m}$ had higher irrigation production efficiency $(6.79 \mathrm{~kg} \mathrm{~m}-3)$ than $6 \times 6$ m (4.70 kg m-3), fruit weight (161.3 g), TSS $\left(11.7^{\circ} \mathrm{B}\right)$ and total sugars $(10.71 \%)$ and vitamin $\mathrm{C}$ contents were superior in fruits obtained from drip-irrigated plants as compared to flood-irrigated ones. Kumar et al., (2013) reported that the Safeda under drip irrigation $0.75 \mathrm{EpR}$ at $120 \% \mathrm{RDF}$ and the highest plant canopy $(38.86 \mathrm{~cm})$ was recorded in L-49 under drip irrigation $0.75 \mathrm{EpR}$ at $120 \%$ RDF. Kachwaya and Chandel (2015) reported that the cultivar chandler had shown the significant effect on plant height, leaf area, fruit yield, maximum fruit length, fruit breadth and fruit weight was also recorded in fertigation with full recommended dose of NPK.

Chandel et al., (2013) studied that fertigation with $3 / 4$ of recommended dose of NPK fertilizers had higher fertilizer-use efficiency than the recommended dose of NPK applied both through drip and soil application, that gave higher net returns without affecting the size, yield and quality of fruits.Kumar et al., (2013) reported that the maximum growth of plants was recorded with 1.0 volume of water through drip along with fertigation of 125 per cent RDF. As well as the maximum yield and economics were observed with 0.8 volume of water through drip along with fertigation of 100 per RDF.

Mali et al., (2015) studied that in litchi highest fruit weight at $60 \%$ ETc with irrigation starting from flowering stage and the prolonged moisture stress between two irrigations under basin system resulted in lowest fruit length, fruit diameter and highest fruit cracking percentage $(10.2 \%)$ and maximum irrigation water use efficiency $(57.1 \mathrm{~g} / \mathrm{m} 3)$ was observed in case of drip irrigation having irrigation at $20 \%$ of Sadarunnisa et al.,(2010) reported that in papaya the maximum yield, no. of fruits/plant, fruit weight was obtained under 75\% drip 
with fertigation which was on par with the yield of plants supplied with $100 \%$ RDF through drip compared to the treatments in which soil application of fertilizers was done.

Tiwari et al., (2013) reported that the water requirement of Sapota crop varies between $2.14 \mathrm{~mm}(10.71 \mathrm{~L})$ per day per plant in winter season and $6.89 \mathrm{~mm}(34.44 \mathrm{~L})$ per day per plant in summer season for $100 \%$ water requirement treatment at peak growth stage and maximum yield of sapota was obtained under $100 \%$ drip with plastic mulch was found to increase by $21.05 \%$ in comparison to ring basin irrigation. Sujatha et al.,(2006) studied that the Drip irrigation in mango cv. Kesar at $0.75 \mathrm{Ep}$ registered higher fruit weight during first year and number of fruits in second year than control (without irrigation). Application of organic and inorganic forms of nutrients individually or in combination increased the fruit number and weight significantly over control. Prakash et al., (2015) studies revealed that the irrigation treatments $13-24 \mathrm{~L} \mathrm{day}^{-1}$ plant $^{-1}$ recorded the highest percentage of fruit set, fruit weight, number of fruits per tree, fruit yield per tree and quality characters like, TSS, ascorbic acid, sugar, carotenoids were also the highest in the same treatment. In case of sub plots percentage of fruit set, fruit weight, number of fruits per tree, fruit yield per tree were recorded by the application of $100 \% \mathrm{RDF}$ through fertigation. Kumari et al., (2014) reported that the irrigation was applied at $75 \%$ ETC and percentage water saving for drip fertigation treatment was $33.94 \%$ over the conventional irrigation. Pramanik et al., (2014) proved that the guava fruits yield increased significantly with increase in application of irrigation water and nitrogen fertilizer. However, maximum fruit yield, higher water use efficiency, net return and $\mathrm{B}: \mathrm{C}$ ratio was registered from drip irrigation at 1.00 Mathura et al., (2002) suggested that in litchi application of potassium @ $249 \mathrm{~g}$
$\mathrm{K} /$ tree/year resulted in the maximum yield $(27.62 \mathrm{~kg} /$ plant$)$, tree height $(3.52 \mathrm{~m})$, spread $(5.50 \mathrm{~m})$ and tree volume $(56.98 \mathrm{~m} 3)$ over control and similarly application of $\mathrm{N}$ significantly influenced tree height, volume, trunk girth, spread, fruit length, fruit volume, TSS and ascorbic acid content.Sharma et al., (2013) Evaluated that highest fruit yield of guava of $18.7 \mathrm{t} / \mathrm{ha}$ was obtained with drip irrigation at $100 \%$ ETc\& $100 \%$ of recommended dose of $\mathrm{N}$ whereas the lowest yield of $11.0 \mathrm{t} / \mathrm{ha}$ was recorded under drip irrigation at 60\% Kachwaya et al., (2016) revealed that drip irrigation at $120 \%$ gave significantly higher fruit yield compared with drip irrigation at 80 and $60 \%$ ETc over furrow irrigation. Similarly, the photosynthetic rate, transpiration rate, number of stomata and size of stomata were higher in drip irrigation at $120 \%$ ETc, followed by drip irrigation at $100 \%$ ETc. Although the physiological performance was slightly better under $120 \%$ ETc in comparison to $100 \%$ ETc drip irrigation, but there was 16-30\% increase in yield in case of $100 \%$ Etc irrigation treatment over furrow irrigations treatment. Singh et al., (2009) reported that drip irrigation at $80 \%$ evapo-transpiration (ET) crop based on pan evaporation applied gave significantly higher fruit yield (45.57 tonnes/ha) compared with the surface irrigation (29.43 tonnes/ha. Ramniwas et al., investigation indicated that the effect of irrigation and fertigation levels showed that $100 \%$ irrigation of cumulative pan evaporation $+100 \%$ water soluble fertilizers gave maximum yield/plant $(6.59 \mathrm{~kg})$.

However, maximum benefit: cost ratio of (2.91) was obtained at $75 \%$ irrigation of cumulative pan evaporation $+75 \%$ water soluble fertilizers. Patil and Das concluded that the nutrient status determined in terms of available N,P,K in $\mathrm{kg} / \mathrm{ha}$ was significantly influenced by different drip irrigation and fertilizer management significantly highest 
fruit yield (87.20 q/ha) was recorded in drip irrigation at 100 EPR along application of 75 $\%$ RDF of $\mathrm{N}$ through drip irrigation over other treatments.

\section{Under plantation crops}

Pramanik et al., reported that the banana was considerable improvement in plant height, pseudo stem girth, leaf area, leaf area index and leaf number with drip irrigation at $70 \%$ of CPE compared to conventional surface irrigation and Maximum fruit yield and water use efficiency (WUE) in main and ratoon crop was obtained with drip irrigation at $60 \% \mathrm{CPE}$ with $80 \%$ of recommended NPK fertilizers.

The maximum yield attributes viz., spathe length, number of inflorescence, number of bunches/palm/year and number of nuts/bunch of $127.76 \mathrm{~cm}, 13,13$ and 31 , respectively were recorded in $100 \%$ of recommended dose of drip fertigation with $100 \mu \mathrm{m}$ polythene mulching. The lowest spathe length, number of inflorescence, number of bunches/palm/year and number of nuts/bunch of $92.16 \mathrm{~cm}, 8,8$ and 12 , respectively were recorded in control treatment without mulch.

Krishnamoorthy and Raja Mani (2013) reported that maximum vegetative parameters like trunk girth increment, Canopy spread, leaf fresh weight and yield of Cocoa were obtained under fertigation with $125 \%$ Krishnamoorthy et al., (2013) concluded that in cocoa fertigation with $125 \%$ RDF as Water Soluble Fertilizers through drip irrigation increased all vegetative growth parameters compared with conventional method of fertilizer application. Husameldin et al., (2013) concluded that $80 \%$ RDF performed well in respect of growth parameters and shortened the total crop duration in banana crop. Dinesh and Ahmed (2014) experimented on almond, results indicated that the maximum tree height $(3.56 \mathrm{~m})$, nut weight (2.73 g), nut yield (5.98 kg/tree; 6.64 $\mathrm{t} / \mathrm{ha})$, and leaf nutrient content $(2.38 \% \mathrm{~N}$; $0.17 \% \mathrm{P} ; 1.41 \% \mathrm{~K}$ ) were recorded in $75 \%$ RDF through fertigation. Sujatha and Ravi et al., (2013) showed that productivity per unit area $\left(\mathrm{kg} \mathrm{ha}{ }^{-1}\right)$ under drip along with fertigation was significant and higher by $12 \%$ in areca nut-cocoa system $(3,450)$ than sole areca nut $(3,090)$ and fertigation at $75 \% \mathrm{RDF}$ improved the yield of cocoa by $52 \%$ over control alone.

\section{Under plastic mulching}

Paul et al.,(2013) studied that the capsicum yield (28.7 t/ha) was recorded maximum under $100 \%$ net irrigation volume with drip irrigation (VD) and plastic mulching and net seasonal income by $57 \%$ and $54 \%$ respectively as compared to conventional surface irrigation without mulch.

Reddy et al., (2015) reported that in tomato highest water use efficiency (1.44) was observed in drip + polythene mulch + trellising followed by drip + polythene mulch (1.26).Singh et al., (2007) reported that guava yields $164 \%$ more yield under drip irrigation when compared with ring basin irrigation and drip with plastic mulching treatment (VDM). Joshi et al., (2012) concluded that treatments in combination with Mulch + drip irrigation at $100 \% \mathrm{WR}+125 \% \mathrm{RDF}$ at each level of fertilizer doses were more effective in improving plant parameters in the first year but in the subsequent years Mulch + drip irrigation at $100 \% \mathrm{WR}+75 \% \mathrm{RDF}$ gave the highest fruit yield. Singh et al., (2009) reported that use of black polyethylene mulch plus drip irrigation further raised the fruit yield to 57.87 tonnes/ha compared to surface irrigation alone or with mulch. Reddy et al., (2015) reported that in tomato Drip + polythene mulch+ trellising given maximum values compared to drip + polythene mulch and drip alone. Seyfi and Rashidi (2007) 
reported that the highest fruit weight and fruit thickness was obtained for the DI + PM treatment and lowest for the CI treatment. The crop yield was highest (27.07 t ha-1) for the DI + PM treatment was found to be more effective irrigation method in improving WUE and increasing cantaloupe yield.

In conclusion, drip irrigation and fertigation technology is beneficial to the farmers for higher production and quality of fruit and vegetable production. Achieving maximum fertigation efficiency requires knowledge of crop nutrient requirements, soil nutrient supply, fertilizer injection technology, irrigation scheduling, crop and soil monitoring techniques.

\section{Acknowledgements}

The authors wish to express their gratitude to the National Com-mittee in Plasticulture Applications in Agriculture and Horticulture (NCPAH), Government of India, Ministry of Agriculture, New Delhi for providing financial support for this study.

\section{References}

Agarwal, N., Sharma, H.G., Dixit, A., Dubey, P., Agarwal, S. 2004. Effect of fertigation through water soluble fertilizers on growth, yield and quality of pomegranate. J. Agr., 9: 13-18.

Ananta, B. 2006. Effect of solid soluble fertilizer applied through fertigation on growth and yield of tomato. Veg. Sci., 33(1): 26-28.

Antony, E., R.B. Singandhupe. 2004. Impact of drip and surface irrigation on growth, yield and WUE of capsicum. J. Agr. Water Manage, 65: 121-132.

Ashokraja, N. 2011. Effect of drip irrigation and fertigation levels on the yield and quality of Muscat grapes (vitisvinifera), 8th International Micro Irrigation
Congress, held at Tehran, IRAN. 305316.

Bao-Zhong Yuan, Soichi Nishiyama, Yaohu Kang. 2003. Effects of different irrigation regimes on the growth and yield of drip-irrigated potato. Agricultural Water Manage, 63: 153167.

Battilani, A., Solimando, D. 2010. Yield, Quality and Nitrogen Use Efficiency of Fertigated Watermelon. Acta Hortic., 700: 10.

Cassel Sharmasarkar, F., S. Sharmasarkar, S.D. Miller, G.F. Vance, R. Zhang. 2001. Assessment of drip and flood irrigation on water and fertilizer use efficiencies for sugar beets. J. Agr. Water Manage, 46: 241-251.

Castellanosa, M.T., Tarquis A.M., Ribas F., Cabello M.J., Arced A., Cartagena M.C. 2013. Nitrogen fertigation: An integrated agronomic and environmental study. Agricultural Water Manage, 120: 46- 55.

Chauhan Neena Chandel, J.S. 2008. Effect of fertigation on growth, yield, fruit quality and fertilizer use efficiency of kiwi fruit (Actinidiadeliciosa. Indian $J$. Agri. Sci., Vol-78: 389-393.

Chun-Zhi Zeng, Zhi-Long Bie, Bao-Zhong Yuan. 2009. Determination of optimum irrigation water amount for dripirrigated muskmelon (Cucumismelo L.. in plastic greenhouse, Agricultural Water Manage, 96: 595 - 602.

Dawelbeit, S., Richter, C. 2004. Fertigation of onion crops by using surface irrigation in Sudan. Rural poverty reduction through research for development. Deutscher Tropentag, October 5-7, Berlin.

Dilip Singh Kachwaya and Chandel, J.S. 2015. Effect of fertigation on growth, yield, fruit quality and leaf nutrients content of strawberry (Fragariax ananassa. cv Chandler. Indian J. Agri. 
Sci., 85(10): 1319-23.

Dilip Singh Kachwaya, J.S., Chandel, Ghumare Vikas, Babita Khachi. 2016. Effect of drip and furrow irrigation on yield and physiological performance of strawberry (Fragariaananassa Duch.. cv. Chandler. Ind. J. Plant Physiol., 21(3): 341-344.

Dinesh Kumar and Ahmed, N. 2014. Response of Nitrogen and Potassium Fertigation to "Waris" Almond (Prunusdulcis. under Northwestern Himalayan Region of India. ScientificWorld J., 201-28.

Dingre, S.K., Pawar, D.D. and Kadam, K.G. 2012. Productivity, water use and quality of onion (Allium cepa. seed production under different irrigation scheduling through drip. Indian $J$. Agron., 57: 186-190

Firake, N.N., Kumbhar, D.B. 2002. Effect of different levels of $\mathrm{N}, \mathrm{P}$ and $\mathrm{K}$ fertigation on yield and quality of Pomegranate. $J$. Maharashtra Agric. Univ., 27: 146-148.

Harmanto, Salokhe, V.M., Babel, M.S., Tantau, S.J. 2005. Water requirement of drip irrigated tomatoes grown in greenhouse in tropical environment, Agri. Water Manage, 71: 225-242.

Hebbar, S.S., B.K., Ramachandrappa, H.V. Nanjappa, M. Prabhakar. 2002. Studies on NPK drip fertigation in field grown tomato. Europe J. Agron., 221: 117127.

Husameldin, H., Mahmoud and Fatima. Y. Gaffer. 2013. Effect of different levels of planting distances, irrigation and fertigation on growth characters of main and ratoon banana crop cv. GrandNaine., Global J. Plant Ecophysiol., 3(2): 104-109.

Imamsahab, S.J., Patil, M.G., Naik, M.K., Hussain, Abbas S. and Ayyangoudar, M.S. 2011. Yield, yield components and quality of processing tomato (Solanumlycopersicum L.. genotypes as influenced by different levels of fertigation. Environ. \& Ecol., 29(1A): 229-232.

Jeyakumar, P., Amutha, A., Balamohan, T.N., Auxcilia, L., Nalina. 2010. Fertigation Improves Fruit Yield and Quality of Papaya. ActaHortic., 851.56

Jose, A., Monte, Daniel, F., de Carvalho, Leonardo, O., Medici, Leonardo, D.B. da Silva and Carlos Pimentel. 2013. Growth analysis and yield of tomato crop under different irrigation depths, Revista Brasileira de Engenharia Agrícola e Ambiental, 17(9): 926-931.

Joshi Ganga, Singh, P.K., Srivastava, P.C., Singh, S.K. 2012. Effect of mulching, drip irrigation scheduling and fertilizer levels on plant growth, fruit yield and quality of litchi (Litchi chinensis Sonn. Indian J. Soil Conservation, Vol 40 (1):46- 51.

Junaid, N., Khan, Jain, A.K., Rakesh Sharda, NavPrem Singh, Gill, P.S.S., Sumanjeet, Kaur. 2013. Growth, yield and nutrient uptake of guava (PsidiumGuavaja L.. affected by soil matric potential, fertigation and mulching under drip irrigation. Agric Eng Int: CIGR J., 15-17.

Kaniszewski, S., Rumpel, J. and Dysko, J. 1999. Effect of drip irrigation and fertigation on growth and yield of celeriac (Apiumgraveolens L. var. rapaceum (Mill.. Gaud. Veg. Crops Res., Bulletin 50: 31-39

Kapoor, R., Sandal, S.K., Sharma Sanjay, K., Kumar, A. and Saroch, K. 2013. Effect of varying drip irrigation levels and NPK fertigation on soil water dynamics, productivity and water use efficiency of cauliflower (Brassica oleracea var. Botrytis. in wet temperate zone of Himachal Pradesh. Indian J. Soil Cons., 42: 249-254

Kohire Patil, V.O. and Das, J.C. 2015. Effect of Drip Irrigation and Fertilizer 
Management on Capsicum (Capsicum Annum L. IOSR J. Agri. Vet. Sci., Vol 8(1): 10-13.

Krishnamoorthy, C. and Rajamani. 2013. Effect of fertigation through drip and micro sprinkler on plant Biometric characters in Cocoa (Theobroma Cacao L.. Pak. J. Boil. Sci.

Krishnamoorthy, C., Rajamani, K. 2013. Effect of Fertigation through Drip and Micro Sprinkler on Plant Biometric Characters in Cocoa (Theobroma cacao L.. Pakistan J. Biol. Sci., 16.24: 19506.

Kumar, Harendra, Kotoky, U. and Devee, A. 2013. Effect of drip fertigation on growth of guava (Psidiumguajava L.. Asian J. Hort., 8(2): 534-536.

Kumar, Harish, Yadav, P.K., Singh, A.K. and Sharma, S.K. 2013. Evaluation of water regime and fertigation on growth, yield and economics of sweet orange (Citrus sinensis Osbeck. cv. Mosambi. Asian J. Hort., 8(2): 709-713.

Liang-zhi Peng, Chun Chang-pin, JiangCailun, wangXuesheng, LiuSheng, Cao Li, LeiTin and Ling Li-li. 2011. The Effects of Drip Fertigation on Tree Growth and Fruiting of Trovita Sweet Orange (Citrussinensis Osbeck) in Calcareous Purple Soil in Chongqing of China, Acta Horticulturae Sinica, 38(1):1-6

Liu Hucheng, Xu Kun, Zhang Yongzheng, Sun Jingqian. 2014. Effect of drip fertigation on yield, water and fertilizer utilization in ginger. Guangdong Agricultural Sci., 2011-24.

Lu Yong-li, Gao Yi-min, Tong Yan-an, Yang Xian-long, Lin Wen. 2013. Effects of fertigation on yield and quality of Fuji apple in Weibei dry-land region. J. Soil and Fertilizer Sci., 01.

Mali, S., Das, B., Singh, A.K. and Bhatnagar. 2015. Effect Of Fruit Stage Based Irrigation Scheduling On Yield, Quality
And Irrigation Water Use Efficiency Of Litchi (Litchi ChinensisSonn.. Cv. Shahi. J. Bioscan, 10(1): 397-401.

Mandal, G., Kumar, S., Kumar, R., Singh, R. 2007. Effect Of Drip Irrigation And Plant Spacing On Yield, Quality And Economic Return Of Guava (Psidium Guajava L.. Grown In Saline Soil Acta Hortic., 735. 60

Mathieu Ngouajio, Guangyao Wang, Ronald Goldy. 2007. Withholding of drip irrigation between transplanting and flowering increases the yield of fieldgrown tomato under plastic mulch, agricultural water management, 87: 285-291.

Muralidhar, A.P., H.R. Shivashankar and V. Kumargoud. 1999. Fertilizer and irrigation efficiency as influenced by furrow and ferti-drip irrigation in capsicum-maize-sunflower cropping sequence. Proceedings of national seminar on problems and prospects of micro irrigation - A critical appraisal, 19-20.

Neelam Patel, Rajput, T.B.S. 2007. Effect of drip tape placement depth and irrigation level on yield of potato, Agricultural Water Manage, 88: 209 - 223.

Neelam, P. and Rajput, T.B.S. 2005. Effects of fertigation on growth and yield of onions. Indian J. Agric. Sci., 77(1): 725-730.

Paul, J.C., Mishra, J.N., Pradhan, P.L., Panigrahi, B. 2013. Effect of drip and surface irrigation on yield, water useefficiency and economics of capsicum (capsicum annum 1.. Grown under mulch and non mulch conditions in eastern coastal India. European J. Sustainable Development 2, 1, 99-108.

Prakash, K., Vijayakumar, R.M., Balamohan, T.M., Sundhar Singh, S.D. 2015. Effect Of Drip Irrigation Regimes And Fertigation Levels On Yield And Quality Of Mango Cultivar 'Alphonso' 
Under Ultra High Density Planting. ActaHortic, 1066-17.

Rai Mathura, Dey, P., Gangopadhyay, K.K., Das Bikash, Nath Vishal, Reddy, N.N., Singh, H.P. 2002. Influence of nitrogen, phosphorus and potassium on growth parameters, leaf nutrient composition and yield of litchi (Litchi chinensis. Indian J. Agri. Sci., vol. 72: 267-270.

Rajbir Singh, Satyendra Kumar, Nangare, D.D. and Meena, M.S. 2009. African J. Agri. Res., Vol. 4 (12. 1427-1430.

Rajput, T.B.S. and Patel, N. 2006. Water and nitrate movement in drip-irrigated onion under fertigation and irrigation treatments. Agric Water Mangnt., 79: 293-311.

Ramniwas, Kaushik, R.A., Sarolia, D.K. 2012. Response of irrigation and fertigation scheduling on flowering, physiological parameters and fruit yield of guava (Psidiumguajava L.. under high density planting. IJAS, ICAR, Vol 33: 3 .

Ramniwas, Kaushik, R.A., Sarola, D.K., Sunil Pareek and Singh, V. 2012. Effect of irrigation and fertigation scheduling on growth and yield of guava (Psidium guajava $\mathrm{L}$. . under meadow orcharding. African J. Agri. Res.,Vol. 7(47): 63506356.

Rao, K.D. and Subramanyam, K. 2009. Effect of nitrogen fertigation on growth and yield of pomegranate var. mridula under low rainfall zone. Agric. Sci. Digest, 29(2).

Ravi Bhat, Sujatha, S., Balasimha, D. 2007. Impact of drip fertigation on productivity of arecanut (Areca catechu L. agricultural water management 90: 101-111.

Roma Kumari, ArunKaushal and Singh, K.G. 2014. Water Use Efficiency of Drip Fertigated Sweet Pepper under the Influence of Different Kinds and Levels of Fertilizers. Indian J. Sci. Technol.,
Vol 7(10): 1538-1543.

Roy, S.S., Khan, M.S.I. and K.K. Pall. 2011. Nitrogen and phosphorus efficiency on the fruit size and yield of capsicum. $J$. Expt. Sci., 2: 32-37.

Sadarunnisa, S., Madhumathi, C., Hari Babu, K., Sreenivasulu, B., Rama Krishna, M. 2010. Effect Of Fertigation On Growth And Yield Of Papaya Cv. Red Lady. ActaHortic., 851: 61.

SanjitPramanik and Patra, S.K. 2014. Influence of fertigation on fruit yield, water use and distribution efficiency and economics of guava (Psidiumguajava L. J. Soil and Water Conservation, 13(2): 164-169.

SanjitPramanik, Ray, R. and Patra, S.K. 2014. Effect of drip vis-à-vis surface irrigation on fruit yield, water use and distribution efficiency of banana in Gangetic plain of West Bengal. Indian J. Hort., 71(2): 176-183.

Sanjit Pramanik, Sonamuni Lai, Ray, R., and Patra, S.K. 2016. Effect of Drip Fertigation on Yield, Water Use Efficiency, and Nutrients Availability in Banana in West Bengal India. Communications In Soil Science And Plant Analysis, Vol (47): 1691-1700.

Seyfi and Rashidi. 2007. Effect of Drip Irrigation and Plastic Mulch on Crop Yield and Yield Components of Cantaloupe. Int. J. Agri. Biol., 247-249.

Shanmugasundaram, T. and Balakrishnamurthy, G. 2013. Effect of fertigation on flowering and yield of tissue culture pomegranate (Punicagranatum L.. cv. Mridula grown under ultrahigh density planting (UHDP. Asian J. Hort., 8(2): 601-604.

Sharma, K. and Mursaleen, N. 2014. Assessment of the Impact of irrigation and fertigation on growth and yield of guava (Psidiumguajava L.. under meadow orcharding. Int. J. Irrigation and Water Manage, 7. 
Shirgure, P.S. 2013. Yield and fruit quality of Nagpur mandarin (Citrus reticulata Blanco. as influenced by evaporation based drip irrigation schedules. Scientific J. Crop Sci., 2(2): 28-35.

Shirgure, P.S., Srivastava, A.K., Singh Shyam. 2003. Irrigation scheduling and fertigation in acid lime (Citrus aurantifolia. Indian J. Agri. Sci., vol. 73: 363-367.

Singandhupe, R.B., James, B.K., Edna, A. and Nanda, P. 2007. Response of drip irrigation and mulching on growth and fruit yield of pointed gourd (Trichosanthesdioica. Indian J. Agri. Sci., 77: 8-13

Singandhupe, R.B., James, B.K., Edanna, Anthony, Nanda, P. and Behera, M.S. 2007. Response of fertigation and mulching on growth and fruit yield of pointed gourd (Trichosanthesdioica. Indian J. Agric. Sci., 77(1): 8-13.

Singandhupe, R.B., Rao, G.G., Patil. M.T. and Brahmanad, P.S. 2002. Fertigation studies and irrigation scheduling in drip irrigation system in tomato crop (Lycopersiconesculentus L.. Europe J. Agro., 19: 327 -340.

Singh, B.K., Tiwari, K.N., Chourasia, S.K., Mandal, S. 2007. Crop Water Requirement of Guava (PsidiumGuajava L.. $\quad \mathrm{Cv}$ Kaji Under Drip Irrigation And Plastic Mulch. Acta Hortic., 735: 56.

Subba Reddy, G.V., Patil, B.V., Srihari Rao, B. and Nagendraprasad, B. 2015. Effect Of Different Types Of Irrigation And Growing Methods On Growth, Yield And water-Use Efficiency Of Tomato (Lycopersicon Esculentum Miller. The bioscan, 10(1): 243-246.

Sujatha S and Ravi Bhat (2013. Impact of drip fertigation on arecanut-cocoa system in humid tropics of India. Agroforest Syst 87:643-656.

Sujatha, S., Rao, J., Reddy, N.N. 2006. Effect of drip irrigation and nutrient management of Mango (Mangiferaindica. in alfisols of semiarid tropics. The Indian J. Agri. Sci., Vol 76: 10.

Suman Sharma, Sanmay Kr. Patra1, Gokul, B. Roy and Soumen Bera. 2013. Influence of Drip Irrigation And Nitrogen Fertigation On Yield And Water Productivity Of Guava. The bioscan, 8(3): 783-786.

Swarajyalakshmi, K.M., Reddy, Deva Muni, Shivashankar, M., Suresh Babu, K. and Nageswara Rao, P. 2005. Studies on response of chilli to different levels of drip irrigation and mulching as compared to basin method of irrigation. In: International conference on plasticulture and precision farming, New Delhi, India.

Tank, R.V. and Patel, N.L. 2013. Influence of fertigation on yield and nutrient status in soil and leaf of papaya (Carica papaya L.. var. MadhuBindhu under south Gujarat condition. Asian J. Hort 8(1): 170-173.

Tiwari, K.N., Mukesh Kumar, Santosh, D.T., Vikas Kumar Singh, Maji, M.K. and Karan, A.K. 2013. Influence of Drip Irrigation and Plastic Mulch on Yield of Sapota (Achraszapota. and Soil Nutrients. Irrigat. Drainage Sys. Eng., Vol 3 (1):1000-116.

Ughade, S.R. and Mahadkar, U.V. 2014. Effect of planting density, irrigation and fertigation levels on water saving and water use efficiency of brinjal (Solanummelongena L.. Adv. Res. J. Crop Improv., 5 (2): 114-117.

Veeranna, H.K., Kgalakabdul, A.A,. Sujith, G.M. 2001. Effect of fertigation with normal and water soluble fertilizers compared to drip and furrow methods on yield, fertilizer and irrigation water use efficiency in chilli. Micro Irrigation, pp. 461-466. 
Vijayakumar, G., Tamilmani, D. and Selvaraj P.K. 2010. Maximizing Water and Fertilizer Use Efficiencies under Drip Irrigation in Chili Crop. Journal of Management and Public Policy, Vol.2.

Vjekoslav Tanaskovik, Ordan Cukaliev, Davor Romić, Gabrijel Ondrašek. 2011. the Influence of Drip Fertigation on Water Use Efficiency in Tomato Crop Production. Agriculturae Conspectus Scientificus, Vol.76:57-63.

Waldir, A., Marouelli, Washington, L.C. Silva. 2007. Water tension thresholds for processing tomatoes under drip irrigation in Central Brazil. Irrig. Sci., 25: 411-418.

Wassel, A.H., Ahmed, F.F., Ragab, M.A. and Ragab, M.M. 2007. Response of balady mandarin trees to drip irrigation and nitrogen fertigation II- Effect of nitrogen fertigation and drip irrigation on fruit setting, number and quality of fruits of Balady mandarin trees (Citrus reticulata. African Crop Sci. Conference Proceedings, Vol (8):513- 522.

\section{How to cite this article:}

Raja Gopala Reddy, A., D.T. Santosh and Tiwari, K.N. 2017. Effect of Drip Irrigation and Fertigation on Growth, Development and Yield of Vegetables and Fruits. Int.J.Curr.Microbiol.App.Sci. 6(2): 1471-1483. doi: http://dx.doi.org/10.20546/ijcmas.2017.602.165 